\title{
PKM Pelaku Usaha Pengolahan Kopi Desa Warnasari Kecamatan Pangalengan Kabupaten Bandung
}

\author{
${ }^{1}$ Yayan Mulyana, ${ }^{2}$ Abdul Rosid, ${ }^{3}$ Erti Dinihayati \\ Jurusan Administrasi Bisnis, Fakultas Ilmu Sosial dan Ilmu Politik, Universitas Pasundan \\ Email: yayan.mulyana@unpas.ac.id, abdul.rosid@unpas.ac.id,ertidinihayati@unpas.ac.id
}

\section{Article Info}

Submitted: 16 October 2020

Revised: 9 March 2021

Accepted: 26 March 2021

Published: 21 April 2021

Keywords: Business,

Processing, Coffee
Kata kunci: Usaha, Pengolahan, Kopi

\section{Abstract}

The activity of this Community Service was carried out in Warnasari Village, in which had potential in the coffee plantation sector based on these observations. Our partners in coffee processing business produce coffee beans (cery) that are going through wet-processed. As for the problems found were the limitation of the equipment in the production process itself (coffee processing machines), limited type of products, coffee beans (cery) processing, insufficient set of skills in utilizing the production equipment, lack of knowledge in the preparation of financial report, as well as the limitation in promoting their coffee products (direct consumers). This PKM (Student Creativity Program) activity aims to provide business actors (entrepreneurs) a well-preserved understanding, especially in Warnasari Village, as to the said problems above. The method used in this Creativity Program is divided into 3 (three) stages, namely the first stage is through observation and direct interviews. The second stage is through implementation by conducting training as needed. The last stage is through coaching, which emphasies the final results of the training. The fact that our business partners received assistance in the form of necessary equipment is the result of the discussion. Moreover, our partners have also started to try additional ventures into processing ground coffee, as well as product development (coffee tea). As for our suggestions, they should be participating more frequent in several training activities so that the ability and willingness of employees is well-known. Furthermore, our business partners should also have their own special employees who handle finances, as well as to have their products promoted to outside of the city by both online and offline systems.
Abstrak
Kegiatan Pengabdian Masyarakat ini dilakukan di Desa Warnasari yang berdasarkan observasi tersebut mempunyai potensi di sektor perkebunan kopi. Mitra pelaku usaha pengolahan kopi menghasilkan biji kopi (cery) yang diolah secara basah. Permasalahan yang ditemukan 
terbatasnya jumlah peralatan dalam proses produksi (mesin pengolah kopi), jenis produk terbatas, pengolahan sampai dengan biji kopi (cery), terbatasnya skill pegawai dalam pemanfaatan dan penggunaan peralatan proses produksi, tidak memiliki dan tidak memahami penyusunan laporan keuangan, serta keterbatasan memasarkan produk kopi (konsumen langsung). Kegiatan PKM ini bertujuan untuk memberikan pemahaman kepada pelaku usaha (wirausaha) khususnya di Desa Warnasari dengan berbagai permasalahan di atas. Metode dalam PKM ini terbagi menjadi 3 (tiga) tahap, yaitu tahap awal melalui observasi serta wawancara langsung. Tahap kedua yaitu Pelaksanaan, melalui pelatihan sesuai kebutuhan. Tahap terakhir, melalui coaching yang menunjukkan hasil dari pelatihan. Hasil dan pembahasan memperoleh bantuan peralatan, mitra sudah mulai mencoba usaha tambahan ke pengolahan kopi bubuk, serta pengembangan produk (teh kopi). Saran sebaiknya sering mengikuti kegiatan pelatihan agar diketahui kemampuan atau kemauan pegawai. Mitra sebaiknya mempunyai pegawai khusus yang menangani keuangan, memasarkan produk ke daerah luar kota dengan sistem online dan offline.

\section{PENDAHULUAN}

Desa Warnasari merupakan bagian/ wilayah dari Kecamatan Pangalengan terletak di bagian selatan Kabupaten Bandung yang berjarak 51 kilometer dari pusat Kota Bandung dan 23 kilometer dari ibu kota Kabupaten Bandung yaitu Soreang. Desa Warnasari yang terletak pada ketinggian +/- $1442 \mathrm{Mdpl}$ dan memiliki suhu udara rata-rata $12-25$ derajat Celcius, menjadi salah satu faktor penentu bahwa salah satu komoditas yang dihasilkan oleh daerah tersebut adalah kopi. Desa Warnasari memiliki 17 Rukun Warga dan 17 kampung yaitu Baru Taraje, Ciawitali, Cibeunying, Cibunihayu, Cidurian, Cipangisikan, Citiis, Kapas, Kiaracondong, Munjul, Neglasari, Padahurip, Palayangan, Parabon, Pasir Ucing, Singkur, dan Wanasari (Segarwati et al., 2020). Luas areal dan produksi kopi terbesar di Jawa Barat terdapat di Kabupaten Bandung. Sentra kopi arabika terbesar di Kabupaten Bandung berada di Kecamatan Pangalengan. Pengusaha kopi arabika asal mulanya hanya di lahan Perhutani yang merupakan peralihan komoditas dari sayuran ke tanaman keras sebagai tanaman penghijauan yang bernilai ekonomi tinggi (Audry \& Djuwendah, 2018). Mitra dalam kegiatan Pengabdian kepada Masyarakat (PKM) adalah pelaku usaha kopi, yaitu produk maupun hasil akhir aktivitas usaha berupa pengolahan kopi.
Pengolahan kopi ini menggunakan pengolahan secara basah. Kopi yang dihasilkan termasuk jenis kopi arabika. Kopi merupakan salah satu komoditas perkebunan unggulan Indonesia. Kopi robusta memiliki kadar kafein sebesar 1,6-2,4\%, lebih tinggi dibanding kopi arabika yang mengandung kafein sebesar 0,9-1,2\%. Fermentasi kopi merupakan salah satu upaya menurunkan kadar kafein kopi (Biologi et al., 2015). Perkebunan kopi tersebar dari Indonesia barat sampai dengan Indonesia timur. Berbeda dengan jenis produksi perkebunan lainnya, sentra kopi di Indonesia mayoritas dimiliki dan dikelola oleh masyarakat daerah tersebut. Jenis kopi yang banyak di hasilkan di Indonesia adalah kopi jenis robusta, yang memiliki harga jual lebih murah dari jenis arabika (Tesavrita \& Martaleo, 2013). Buah kopi yang sudah dipanen segera harus diolah untuk mencegah terjadinya reaksi kimia yang bisa menurunkan mutu kopi. Secara umum dikenal dua cara mengolah buah kopi menjadi biji kopi, yaitu proses basah dan proses kering. Selain itu, ada juga proses semi basah atau semi kering, yang merupakan modifikasi dari kedua proses tersebut. Setiap cara pengolahan mempunyai keunggulan dan kelemahan, baik ditinjau dari mutu biji yang dihasilkan maupun komponen biaya produksi.

Berdasarkan analisis situasi pelaku usaha (mitra) pengolahan kopi ditemukan berbagai 
permasalahan yang berhubungan dengan usaha, diantaranya:

a. Permasalahan produksi, terbatasnya jumlah pegawai dan kapasitas produksi dalam jumlah peralatan mesin pengolah biji kopi.

b. Permasalahan produk, terbatasnya pengolahan bahan baku buah kopi (cery) tersebut hanya sampai dengan biji kopi (gabah).

c. Permasalahan SDM, terbatasnya kompetensi, skill/keunggulan pegawai dalam pemanfaatan dan penggunaan peralatan dan proses produksi

d. Permasalahan manajemen keuangan, belum memiliki laporan keuangan,

e. Permasalahan Pemasaran, minimnya informasi dalam memasarkan produk

Solusi dari permasalahan kelima hal tersebut adalah sebagai berikut:

a. Peningkatan peralatan mesin pengolah biji kopi serta pemahaman pegawai dalam menggunakan peralatan yang dimaksud.

b. Peningkatan pengolahan produk buah kopi (cery) sampai biji kopi (gabah).

c. Peningkatan pemahaman terhadap manajemen keuangan, terutama laporan keuangan.

d. Peningkatan memasarkan produk biji kopi melalui berbagai media

Luaran dari kegiatan PKM ini adalah pelaku usaha mampu meningkatkan peralatan mesin yang dibutuhkan serta pegawai memahami penggunaan peralatan tersebut, mampu meningkatkan pengolahan dengan bahan baku kopi, mampu meningkatkan pemahaman pencatatan masuk (pendapatan) dan keluar (biaya-biaya/beban), serta mampu meningkatkan memasarkan produk kopi.

Usaha Mikro Kecil dan Menengah (UMKM) menjadi pembahasan berbagai pihak bahkan UMKM dianggap sebagai penyelamat perekonomian Indonesia di masa krisis pada periode 1998-2000. Peran masyarakat dalam pembangunan nasional, utamanya dalam pembangunan ekonomi adalah Usaha Mikro, Kecil, dan Menengah. Posisi Usaha Mikro, Kecil, dan Menengah (UMKM) dalam perekonomian nasional memiliki peran yang penting dan strategis (Sarfiah et al., 2019). Berbagai peran strategis dimiliki sektor UMKM, namun sektor ini juga dihadapkan berbagai permasalahan. Kendala dan permasalahan antara lain dari aspek permodalan, kemampuan manajemen usaha, dan kualitas sumber daya manusia pengelolanya (Supriyanto, 2012). Kendala dan permasalahan usaha kecil dan informal lainnya juga disebabkan karena sulitnya akses terhadap informasi dan sumber daya produktif seperti modal dan teknologi, yang berakibat menjadi terbatasnya kemampuan usaha kecil untuk berkembang. UMKM mempunyai ciri khas, yaitu modal yang kecil, risiko yang sedikit tinggi tetapi return juga tinggi, dan membawa kewirausahaan bagi pemiliknya. Konsep kewirausahaan memberikan arti bahwa wirausahawan merupakan seseorang yang bertindak membuat organisasi, mengelolanya, dan menentukan risiko sebuah bisnis/usaha. Wirausaha merupakan tindakan seseorang yang berani menanggung risiko sebuah bisnis, adanya pertumbuhan bisnis, hasilnya akan meningkatkan kapitalisasi perusahaan. Wirausaha juga dihubungkan terhadap inovasi karena tindakan bisnis yang dihasilkan bisa sangat unik dan mempunyai inovasi tinggi. Dapat disimpulkan bahwa wirausaha harus memiliki motivasi, kerja keras, mempunyai jaringan (network), inovasi dan keinginan bertumbuh, serta pengambil risiko.

Program pengabdian pada masyarakat yang dilaksanakan oleh Perguruan Tinggi (PT) adalah salah satu dari implementasi Tridharma PT. Program ini dilaksanakan dalam berbagai bentuk misalnya; pendidikan dan pelatihan masyarakat, pelayanan masyarakat, dan kaji tindak dari Iptek yang dihasilkan oleh PT. Tujuan program ini adalah menerapkan hasil-hasil Iptek untuk pemberdayaan masyarakat sehingga menghasilkan perubahan pengetahuan, keterampilan, dan sikap dari kelompok masyarakat sasaran (Noor, 2010). Sehingga Kegiatan PKM ini bertujuan untuk memberikan pemahaman kepada mitra sebagai pelaku usaha (wirausaha) khususnya di Desa Warnasari dengan berbagai permasalahan-permasalahan seperti yang dipaparkan di atas.

\section{METODE}

Secara umum metode yang dilakukan dalam pelaksanaan PKM ini adalah melakukan 
langkah-langkah dengan 3 (tiga) tahap mulai dari tahap awal, tahap pelaksanaan, maupun tahap akhit (monitoring dan evaluasi). Tahap awal dilakukan dengan cara observasi ataupun wawancara secara langsung dengan mitra, hal ini dilakukan agar tim pelaksana mengetahui apa yang menjadi permasalahan mitra. selanjutnya tahap pelaksanaan tim pelaksana memberikan pelatihan kepada mitra sesuai dengan permasalahan yang ada baik dari aspek produksi, sumber daya manusia, keuangan, maupun pemasaran, dengan harapan melalui pelatihan tersebut diharapkan pelaku usaha dapat mengetahui perkembangan usahanya. Dan terakhir tahap monitoring dan evaluasi, di mana pelaku usaha/mitra dapat menjelaskan perbedaan pada saat sebelum atau setelah diberikan pelatihan empat aspek tersebut.

Metode pelaksanaan kegiatan menjelaskan tahapan atau langkah-langkah dalam melaksanakan solusi yang telah ditawarkan untuk mengatasi permasalahan yang terdapat pada mitra baik di bidang produksi, sumber daya manusia, keuangan, maupun pemasaran. Tahapan/ langkah-langkah mengatasi permasalahan di bidang :

1. Produksi

Tim pelaksana mengidentifikasi, mengamati dan mencatat jumlah peralatan (mesin pengolah biji kopi), perlengkapan proses produksi, serta pengadaan bahan baku yang tersedia di tempat mitra.

2. Sumber daya manusia

Tim pelaksana mengidentifikasi dan mencatat jumlah pegawai yang ada, mengamati pemanfaatan, maupun penggunaan peralatan dan perlengkapan proses produksi.
3. Keuangan

Tim pelaksana mengidentifikasi, mengamati dan mencatat aktivitas mitra dalam melakukan kegiatan pembukuan keuangan

4. Pemasaran

Tim pelaksana mengidentifikasi, mengamati, dan mencatat aktivitas mitra dalam melakukan kegiatan pemasaran. Secara lebih jelas metode yang digunakan dalam pengabdian dapat dilihat pada Gambar 1.

\section{HASIL DAN PEMBAHASAN}

Kegiatan PKM ini diselenggarakan di Desa Warnasari, Kecamatan Pangalengan, Kabupaten Bandung, beranggotakan 3 (tiga) orang, yaitu ketua pelaksana, anggota tim sebanyak 2 (dua) orang serta dibantu oleh 2 (dua) mahasiswa yaitu Septrian Gumilang Rusmana NPM 162040015 dan Rones Yulian NPM 162040097. Tim Pelaksana dan mahasiswa berasal dari Prodi Ilmu Administrasi Bisnis FISIP Universitas Pasundan Bandung. Kegiatan PKM ini di danai oleh fakultas serta tidak mendapatkan bantuan dana dari pihak lain/luar.

Sebelum kegiatan PKM ini dilaksanakan, tim pelaksana terlebih dahulu melakukan survei lapangan. Diawali dengan mendatangi Kantor Desa untuk melaporkan kegiatan yang dimaksud serta mengurus perizinan. Proses perizinan dari Kantor Desa mudah dan lancar, karena sebelum kegiatan PKM ini dilaksanakan terlebih dahulu, Fakultas melakukan kegiatan pengabdian masyarakat dengan melibatkan lima Prodi di lingkungan Fisip Unpas. Survei lapangan oleh Tim pelaksana menentukan mitra yang terpilih. Kopi di Pangalengan umumnya dijual petani dalam bentuk gelondongan basah (chery) kepada koperasi, badar, dan usaha pengolahan kopi. Saat

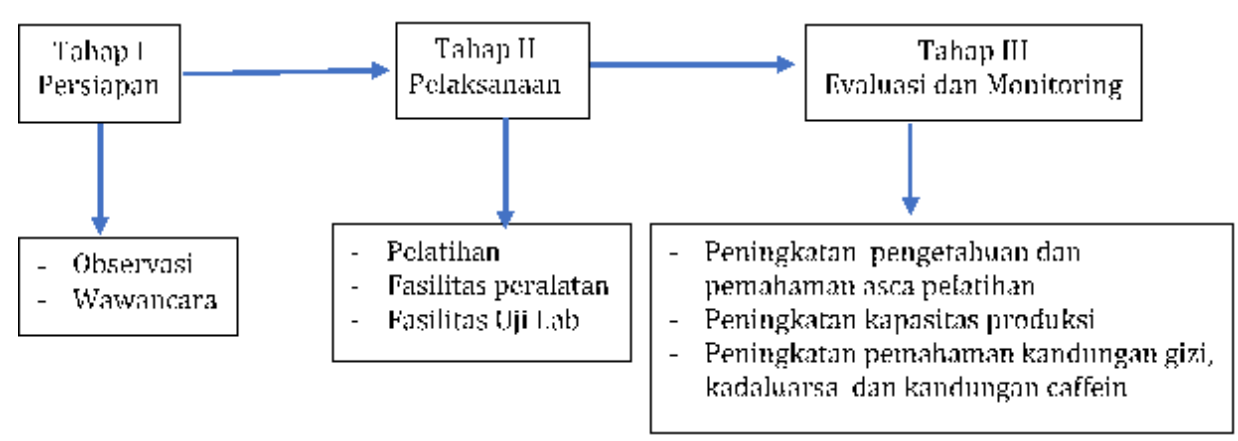

Gambar 1. Proses Kegiatan Pengabdian 
ini terdapat 5 pabrik pengolahan di Pangalengan berbentuk badan usaha koperasi, Perseroan Terbatas (PT) maupun perusahaan perseorangan. Pelaku agroindustri kopi tersebut melakukan pengolahan kopi java preanger menjadi green bean, roasted bean dan ground coffee yang sesuai dengan kebutuhan konsumen (Djuwendah et al., 2018). Mitra dari kegiatan PKM adalah Bapak H. Encang Dasman pemilik usaha pengolahan kopi. Biji kopi (gabah) yang diolah oleh mitra merupakan jenis kopi arabica. Kegiatan PKM ini difokuskan pada bidang usaha pengolahan kopi, jika dilihat secara kriteria usaha mitra termasuk kedalam usaha mikro kecil. Seperti paparan sebelumnya ketertarikan Tim pelaksana terhadap mitra adalah pengolahan/proses produksi hanya sampai diarahkan kepada hasil biji kopi (gabah) saja, sementara melihat kondisi saat sekarang terutama di daerah Desa Warnasari umumnya Kecamatan Pangalengan banyak bermunculan usaha minum kopi (coffe shop). Berdasarkan informasi, di daerah Kampung Pojok semua penduduk menjadi petani kopi, pengolah kopi, sampai ke usaha minum kopi. Alasan mitra tetap mempertahankan biji kopi (gabah), adalah membuka kesempatan/peluang kepada pihak lain untuk usaha pengolahan kopi (beras/bubuk). Saat ini kopi telah menjadi gaya hidup (social life style) di kota-kota besar dunia (Cowan, 2005) tidak hanya di kalangan kaula muda, tetapi juga pada kalangan dewasa.(Id, 2020)

Berdasarkan tahap awal kegiatan bahwa berkaitan dengan data yang diperlukan, berikut digambarkan hasil observasi dan wawancara dengan mitra sebagai berikut:

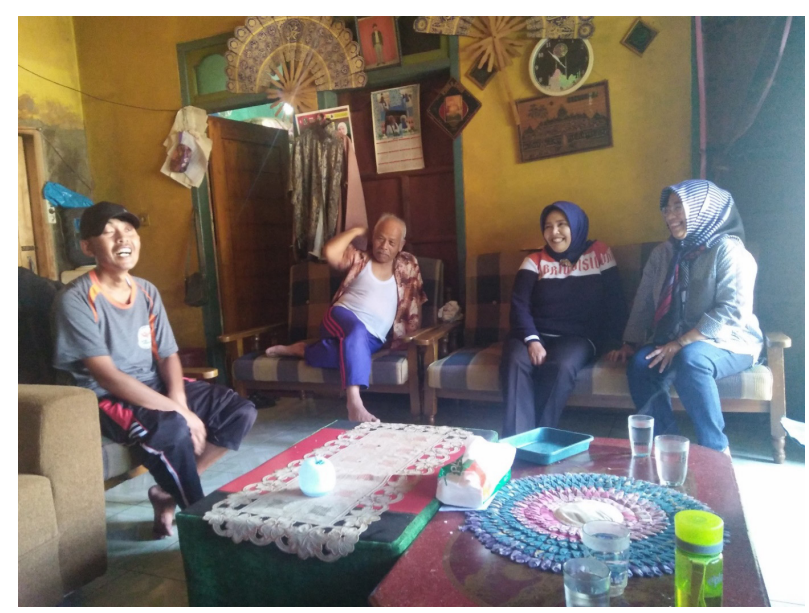

Gambar 2. Diskusi Analisis Situasi Tim Pelaksana dengan Mitra
Usaha Mikro, Kecil, dan Menengah (UMKM) bertujuan menumbuhkembangkan usaha dalam rangka membangun perekonomian nasional berdasarkan demokrasi ekonomi yang berkeadilan. Hal ini mengandung makna, bahwa UMKM merupakan alat perjuangan nasional untuk menumbuhkan dan membangun perekonomian nasional dengan melibatkan sebanyak mungkin pelaku ekonomi berdasarkan potensi yang dimiliki atas dasar keadilan bagi semua pemangku kepentingan. Menurut Undang-Undang No. 20 Tahun 2008 tentang UMKM, menjelaskan bahwa yang dimaksud dengan usaha mikro adalah usaha produktif milik orang perorangan dan/atau badan usaha perorangan yang memenuhi kriteria usaha mikro sebagaimana diatur dalam UndangUndang. Kriteria yang dimaksud apabila: (1) Memiliki kekayaan bersih paling banyak Rp. 50.000.000 tidak termasuk tanah dan bangunan tempat usaha; (2) Memiliki hasil penjualan tahunan paling banyak Rp. 300.000.000. Latar belakang pengusaha kecil lebih beragan dari usaha mikro, walaupun latar belakang ekonomi juga merupakan alasan yang utama, tetapi sebagian lain mempunyai latar belakang lebih realistis dengan melihat prospek usaha ke depan dengan kendala modal yang terbatas. sebagian besar pengusaha mikro/kecil mempunyai alasan berusaha karena adanya peluang bisnis dan pangsa pasar yang aman dan besar. Ada juga sejumlah pengusaha mikro/ kecil berusaha dengan alasan utamanya karena faktor keturunan/warisan, dibekali keahlian dan membuka lapangan kerja baru bagi warga setempat. Berdasarkan penjelasan dan kriteria tersebut, mitra (pelaku usaha pengolahan kopi) dalam kegiatan PKM termasuk kepada usaha mikro, karena secara kriteria kekayaan, hasil penjualan tahunan, dan jumlah karyawannya kurang dari 10 (sepuluh) orang sudah terpenuhi. Motivasi ekonomi, ingin menangkap peluang serta prospek usaha, juga menjadi alasan mitra mempertahankan usaha, selain karena usaha pengolahn kopi karena warisan dari keluarga, serta keinginan kuat mitra dalam memberdayakan masyarakat sekitar melalui perekrutan tenaga-tenaga kerja/pegawai.

Pada dasarnya, organisasi didirikan dengan suatu tujuan. Jika bentuk organisasi dan tujuannya baik, tetapi kerja sama dan 
derap langkahnya kurang baik dan tak seirama, tujuan tersebut tak akan tercapai. Oleh karena itu, pemimpin harus dapat mewujudkan kerja sama yang baik, dan sekaligus bertindak sebagai perencana, organisator, penggerak, dan pengawas (Pembina) bawahan. Dalam semua organisasi, sebagaian besar tingkat keberhasilan bergantung pada kualitas manajemen, untuk itu manajer harus melibatkan kemampuannya untuk mengatasi variable-variabel operating dengan cara-cara yang lebih berpengaruh dalam mencapai sasaran-sasaran organisasi. Ia pun harus mampu melaksanakan perubahanperubahan yang akan mencapai atau membantu terciptanya sasaran-sasaran tersebut.

Dalam upaya mendukung metode yang ditawarkan, maka diperlukan prosedur kerja yang meliputi langkah-langkah sebagai berikut:

1. Tahap persiapan/menyusun kegiatan, dalam tahap ini tim pelaksana melakukan berbagai persiapan awal mulai dari laporan/perizinan kepada pihak terkait di wilayah (kantor Desa, RW, RT/Dusun) tim melaksanakan PKM, selanjutnya mengidentifikasi mitra dimaksud serta permasalahan-permasalahan di aspek usaha.

2. Tahap koordinasi tim pelaksana, dalam tahap ini ketua tim berkordinasi dengan anggota untuk kesiapan selama kegiatan mulai awal, pelaksanaan, sampai akhir kegiatan dengan menjalankan tugas dan fungsi masing-masing.

3. Tahap penyiapan pelatih/pembimbing teknis/pendamping dan mitra, tahap ini tim pelaksana menyiapkan pelatih sesuai dengan permasalahan yang ditemukan di mitra, serta penyesuaian pelatih dari keahliannya masing-masing, baik pelatih intern tim pelaksana maupun pelatih ekstern.

4. Tahap penyusunan jadwal kegiatan program, Tahap ini Tim Pelaksana melakukan pembuatan jadwal kegiatan sesuai dengan yang disepakati dengan tujuan agar kegiatan ini terselenggara tepat waktu, walau di lapangan ditemukan kendala-kendala.

5. Tahap pelaksanaan kegiatan pelatihan/ pembimbing teknis/pendamping dan fasilitasi, tahap ini tim pelaksana bertindak sebagai tim pelaksana maupun pelatih, pembimbing, maupun fasilitator, ditambah kegiatan pelatihan oleh pelatih ekstern.

6. Tahap pelaksanaan monitoring dan evaluasi, tahap ini tim pelaksana melakukan kegiatan monitoring serta evaluasi terhadap perkembangan usaha mitra, monitoring dilakukan di tengah kegiatan pelaksanaan PKM, dan evaluasi setelah dilakukan saat dan setelah kegiatan berakhir.

Tanaman kopi merupakan komoditas perkebunan andalan yang menjadi salah satu komoditas penghasil devisa bagi Indonesia. Seperti halnya produk pertanian lainnya, buah kopi yang telah dipanen perlu segera diolah menjadi tahapan yang bisa disimpan dalam jangka waktu tertentu. Secara umum terdapat 2 (dua) cara pengolahan buah kopi menjadi biji kopi yaitu cara olah basah dan cara olah kering. Setiap cara pengolahan memiliki keunggulan dan kelemahan tersendiri. Secara biaya produksi olah basah membutuhkan biaya yang lebih tinggi dibandingkan olah kering. Sedangkan dari segi kualitas produksi kopi yang dihasilkan dari proses olah basah memiliki kualitas yang lebih baik. Umumnya cara olah basah digunakan pada jenis kopi arabica, karena kopi jenis arabika memiliki nilai jual yang lebih tinggi disbanding robusta. Tahapan pengolahan biji kopi dengan proses basah terdiri dari : panen, sortasi buah, pengupasan kulit buah, fermentasi, pencucian, pengeringan, pengupasan kulit taanduk dan kulit ari, sortasi biji kopi, dan pengemasan, serta penyimpanan. Buah kopi yang telah dipanen harus segera diolah untuk mencegah terjadinya reaksi kimia yang bisa menurunkan mutu kopi. Hasil panen dipilah berdasarkan kriteria tertentu. Buah kopi dengan kualitas yang baik bila diolah dengan benar akan menghasilkan biji kopi bermutu tinggi.

Buah kopi mengalami beberapa tahapan sebelum akhirnya menjadi biji kopi bersih berjenis greenbeans. Pengolahan buah kopi terbagi menjadi dua area utama, yaitu area perkebunan dan area pabrik. Pertama-tama buah kopi dipetik dan disortasi di area perkebunan kopi oleh petani. Selanjutnya buah kopi hasil sortasi tersebut akan dibawa ke area pabrik untuk melalui proses pengupasan kulit buah 
(pulping), fermentasi, pencucian, pengeringan I, pengupasan kulit tanduk (hulling), pengeringan II, dan sortasi. Setelah proses sortasi kedua, biji kopi akan dikelompokkan berdasarkan grade dan dimasukkan ke dalam karung untuk kemudian disimpan di gudang. (Tesavrita \& Martaleo, 2013)

Untuk pengolahan kopi yang dilakukan oleh LMDH adalah setelah memetik buah kopi, buah kopinya dikupas menggunakan mesin, lalu dilakukan fermentasi terhadap biji yang telah dikupas dengan cara direndam semalaman dengan air bersih, setelah direndam lalu dicuci sampai bersih dan siap untuk dijemur sampai kering. Setelah itu biji kopi siap untuk dijual dan dipasarkan kepada konsumen. Pengolahan kopi LMDH ini hanya sampai berbentuk gabah kopi. Karena LMDH belum memiliki mesin untuk membuat kopi menjadi berasan atau kopi bubuk, maka proses yang dilakukan hanya sampai gabah kopi. Konsumen yang dimiliki oleh LMDH kebanyakan berasal dari para pemilik kedai kopi, café, dan tempat makan. Peningkatan mutu kopi dapat dilakukan melalui pengolahan cara basah. Pengolahan kopi cara basah dapat menghasilkan mutu yang lebih baik, aroma, serta rasa kopi yang enak sehingga harga kopi dapat lebih terjamin, hanya saja memakan waktu lebih lama disbanding pengolahan kering. Pengolahan kopi cara basah adalah proses pengolahan buah kopi yang menggunakan air sebagai pengolahan (perendaman dan pencucian). Pengolahan basah dapat dilakukan untuk skala kecil (tingkat petani), menengah (semi mekanis dan mekanis), maupun skala besar.

Berikut adalah proses yang harus dilakukan dalam pembuatan pengolahan kopi sampai dengan gabah kopi pada Mitra sebagai berikut :

a. Pemeriksaan Bahan

Sebelum mulai produksi, buah kopi dipilih berdasarkan kematangan buah dan biasanya berwarna merah. Jika masih berwarna hijau berarti buah kopi tersebut belum bisa diolah karena masih mentah.

b. Pengecekan Kelengkapan Peralatan dan Perlengkapan

Jika bahan baku sudah diperiksa dan sudah siap, maka saatnya untuk mengecek mesin pengupas kulit apakah berfungsi dengan baik atau tidak serta beberapa peralatan lainnya seperti tampah besar untuk menyaring dan kain terpal untuk menjadi alas untuk menjemur biji kopinya nanti.

c. Pengupasan Kulit Buah Kopi

Setelah buah kopi yang sudah dipetik langsung dari kebun datang ke tempat produksi, hal pertama yang harus dilakukan adalah mengupas kulit buah kopi menggunakan mesin pengupas kulit. Prosesnya mudah, hanya dengan cara memasukkan buah kopi ke dalam mesin, dan menyimpan karung di tempat biji kopi yang telah selesai dikupas akan keluar dari mesinnya.

d. Fermentasi Biji Kopi

Setelah dikupas, proses selanjutnya adalah fermentasi terhadap biji kopi yang telah dikupas. LMDH masih menggunakan cara yang sangat sederhana yaitu dengan cara direndam semalaman, lalu pada pagi harinya biji kopi dibersihkan dan disiap dijemur.

e. Penjemuran Biji Kopi

Proses yang terakhir adalah penjemuran biji kopi. Setelah direndam semalaman, biji kopi diambil menggunakan tampah besar dan dibawa menuju tempat penjemuran yang telah dialasi oleh kain terpal. Agar biji kopi terjemur rata dan tidak bertumpuk, maka dirapikan menggunakan sapu garpu.

f. Pengemasan Produk

Setelah kering dan selesai dijemur, maka biji kopi siap untuk dikemas. LMDH masih menggunakan karung untuk mengemas biji kopinya, karena biasanya konsumen membeli borongan. Maka packaging masih berupa karung besar. Setelah dikemas, produk sudah siap dipasarkan kepada konsumen.

Berikut ini merupakan gambar alur proses produksi dari pengolahan kopi sampai dengan gabah: 


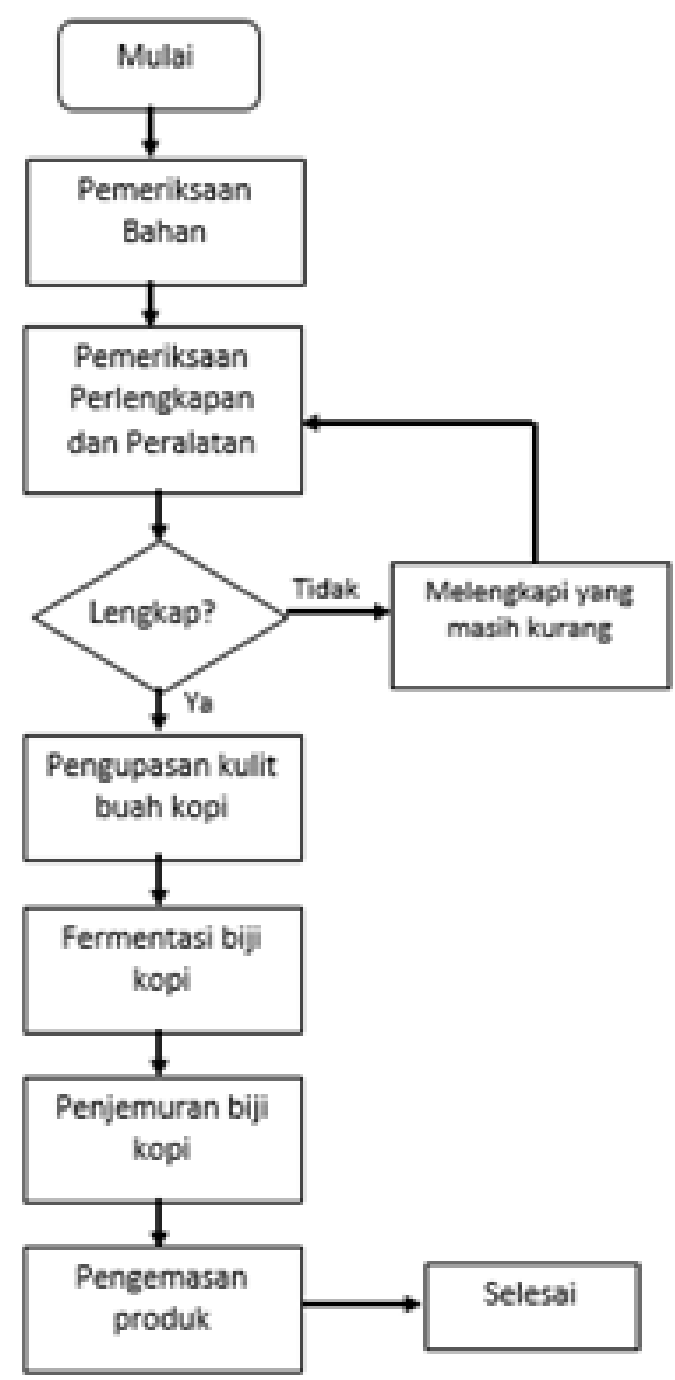

Gambar 3. Alur Proses Produksi

Berdasarkan tabel di atas, daftar inventaris yang dimiliki LMDH sangat sederhana meliputi mesin pengupas kulit, timbangan, tampah besar, sapu garpu, dan kain terpal dengan total harga Rp. 10.794.000. Berdasarkan data di atas, mesin pengupas kulit hanya ada 1 unit yang digunakan untuk produksi setiap harinya. Ada pula tampah besar yang digunakan untuk membawa biji kopi yang telah direndam semalaman agar bisa tersaring dan airnya bisa terbuang. Lalu setelah itu dijemur di atas kain terpal, dan diratakan agar tidak ada yang menumpuk menggunakan sapu garpu.

Untuk menjalankan kegiatan usaha diperlukan tempat usaha yang dikenal dengan lokasi. Lokasi ini penting baik sebagai tempat menjalankan aktivitas yang melayani konsumen, aktivitas produksi, aktivitas penyimpanan, ataupun untuk mengendalikan kegiatan perusahaan secara keseluruhan. Disamping lokasi perusahaan, perlu juga dipikirkan tata letak/lay out sebagai tempat melakukan kegiatan usaha. Lay out yang perlu dilakukan adalah terhadap gedung, parker, bentuk gedung dan lainnya yang berkaitan dengan gedung tersebut, kemudian lay out ruangan beserta isinya, kursi, meja lemari, mesin, peralatan, dan sebagainya.

Berdasarkan lay out gambar tersebut, tempat produksinya berbentuk lapangan kecil untuk menjemur biji kopi yang telah diolah, dari mulai pengupasan kulit kopi, fermentasi terhadap biji kopi yang telah dikupas, lalu setelah itu dijemur hingga kering dan siap pasarkan. Kualitas bubuk kopi dapat dilihat dari sifat fisik dan kimianya. Sifat fisik diantaranya adalah tekstur, warna, aroma dan rasa sedangkan yang termasuk dalam sifat kimia yang menjadi ciri khas dari kopi bubuk adalah, kadar air, keasaman (pH) dan kandungan kimia dalam bubuk kopi tersebut. Unsur-unsur tersebut harus sesuai dengan standar mutu (SNI), agar dapat diterima oleh konsumen.(Edowai \& Tahoba, 2018).

Instalasi sarana penunjang berkaitan dengan tata letak (layout) yang termasuk dalam anggaran investasi. Pemasangan sarana

Tabel 1. Daftar Inventaris/Perangkat Kerja

\begin{tabular}{|c|c|c|c|c|}
\hline Inventaris / Perangkat Kerja & Merek & Jumlah Unit & Harga & Jumlah Harga \\
\hline Mesin Pengupas Kulit & - & 1 unit & Rp. 7.500 .000 & Rp. 7.500 .000 \\
\hline Timbangan & - & 1 unit & Rp. 1.350 .000 & Rp. 1.350 .000 \\
\hline Tampah Besar & - & 5 buah & 15.000 & 75.000 \\
\hline Sapu Garpu & - & 3 buah & 23.000 & 69.000 \\
\hline Kain Terpal & - & 8 buah & Rp. $\quad 225.000$ & Rp. 1.800 .000 \\
\hline Total Inventaris Kantor & & & & Rp. 10.794 .000 \\
\hline
\end{tabular}

Sumber: Hasil Wawancara dengan Sekretaris LMDH, Tahun 2019 


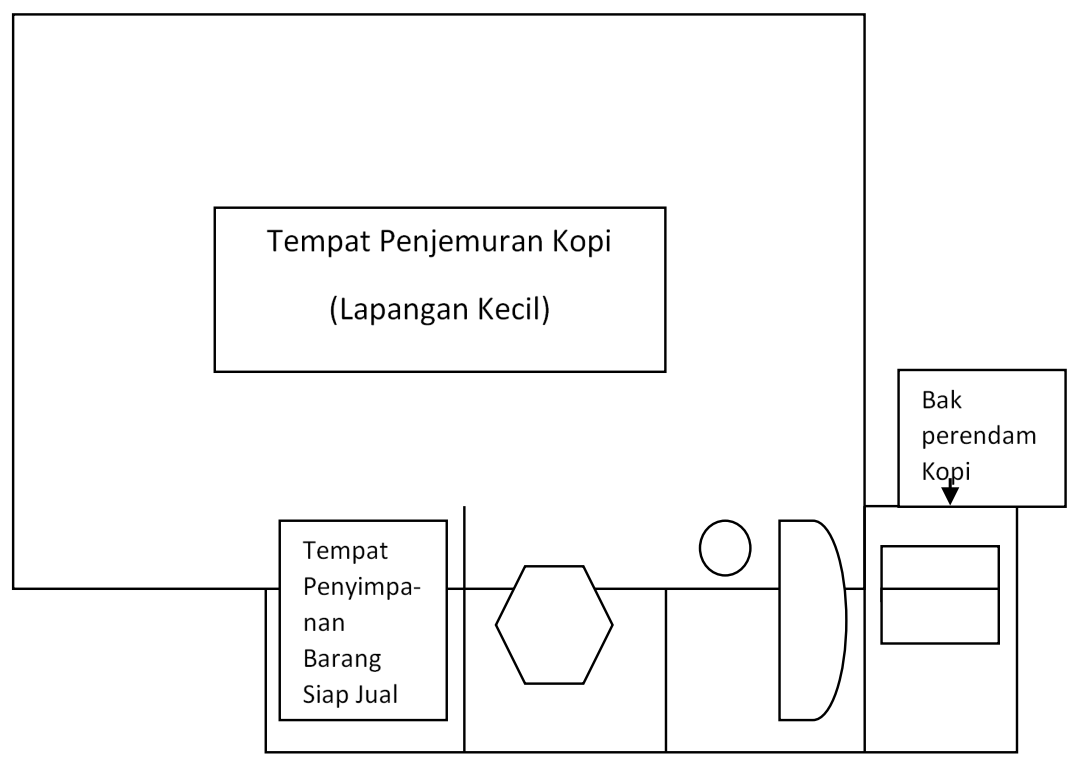

Keterangan:

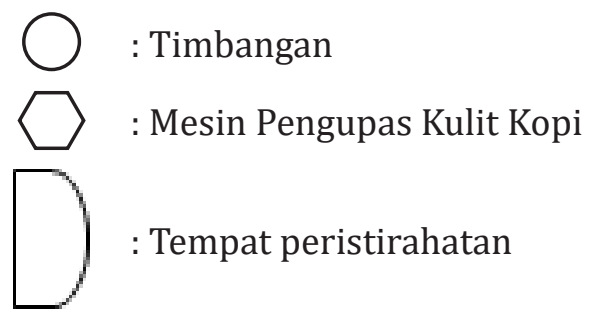

Gambar 4. Lay out Tempat Produksi Pengolahan Kopi

penunjang ini hanya meliputi mesin pengupas kulit saja. Karena untuk pemasangan listrik dan air di Kampung Wanasari masih sederhana. Hanya untuk membayar iuran bulanan saja, bukan membayar sejumlah listrik yang telah digunakan.

Sesuai dengan solusi yang diharapkan dalam meningkatan kapasitas jumlah peralatan (mesin pengolah kopi) dan perlengkapan proses produksi, serta pengadaan bahan baku luaran yang diperoleh dalam kegiatan ini bahwa tim pelaksana belum dapat memenuhi kebutuhan mitra dalam pengadaan mesin pengolah kopi (Huller), dikarenakan harga sebuah mesin harga kisaran Rp.7.500.000-Rp. 15.000.000, selain itu keterbatasan tim dalam memperoleh bantuan dana dari kegiatan PKM. Sebagai alternatifnya sesuai dengan keinginan mitra bahwa pengadaan mesin pengolah/pengupas kopi (coffee pulper machine) dialihkan ke mesin pengolah/pengupas kopi dari biji menjadi bubuk kopi dengan alat/ mesin grinder (coffe grinder mesin). Hal yang mendasari pengalihan alternative mesin bahwa mitra ke depannya sudah mempersiapkan usaha lanjutan dari pengolahan biji kopi menjadi bubuk kopi. Hal ini diperkuat berdasarkan hasil wawancara dengan mitra, sudah mempersiapkan tenaga-tenaga kerjanya yaitu para pemuda yang direkrut dari sekitar obyek mitra, serta sudah mengusahakan kegiatan usaha mitra ke dalam bentuk yayasan. Berkaitan dengan fasilitasi bantuan peralatan untuk kebutuhan mitra, dijelaskan ke dalam gambar sebagai berikut :

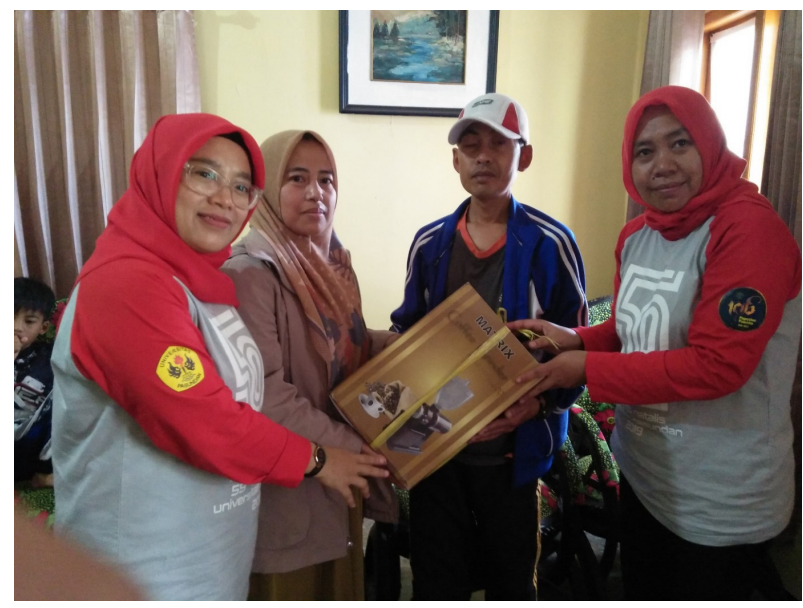

Gambar 5. Penyerahan Bantuaan Peralatan untuk Mitra 
Solusi yang diharapkan dalam peningkatan skill/ kompetensi pegawai dalam pemanfaatan dan penggunaan peralatan dan perlengkapan proses produksi melalui pelatihan/bimteks/ pendampingaan, luaran yang yang diperoleh dalam kegiatan ini bahwa tim pelaksana mengevaluasi bahwa tidak semua karyawan dapat mengoperasikan peralatan proses produksi, hanya 1 (satu) orang yang dipercayai pihak mitra untuk mengoperasikan peralatan yaitu Bapak Enang selaku anak dari Bapak H. Encang Dasman.

Solusi dalam meningkatkan pengadaan bahan baku Kopi (Mitra kerjasama dengan pihak lain) serta solusi jenis produk terbatas, pengolahan hanya sampai dengan biji kopi (cery), Solusi dalam pelatihan/bimteks/ pendampingan pengembangan produk, dan Solusi dalam peningkatan pemasaran produk kopi untuk mendapatkan konsumen/pasar baru, luaran yang yang diperoleh dalam kegiatan ini bahwa tim pelaksana meyakinkan mitra dengan usaha pengembangan produk biji kopi menjadi kopi bubuk sebagai suatu usaha peningkatan penambahan penghasilan, hal ini telah difasilitasi oleh tim dengan pengadaan alat/mesin grinder. Pengembangan produk kopi juga diarahkan kepada daun kopi untuk dijadikan teh kopi dan sudah mulai dijalankan oleh tenaga kerja pemuda sekitar obyek mitra. Tim pun mengevaluasi hasil kegiatan PKM dalam hal pemasaran, bahwa mitra harus mempunyai tenaga khusus untuk memasarkan produk kopi.

Setelah produk yang dihasilkan oleh LMDH ini sampai di tangan konsumen, berikutnya tergantung dari pengolahan lanjutan yang dilakukan oleh konsumen. Ada beberapa manfaat yang bisa dihasilkan dari kopi ini. Berikut adalah penjelasan dari berbagai manfaat yang bisa didapat dari mengonsumsi kopi:

\section{a. Meningkatkan Fungsi Otak}

Manfaat kopi bagi otak sangat banyak, karena kopi mengandung kafein. Kafein yang terkandung dalam kopi dapat membuat otak bekerja lebih baik. Otak dapat memproses informasi lebih cepat dan membuat otak lebih fokus. Kafein dapat dengan cepat meningkatkan fungsi otak, karena itu rasa kantuk seseorang bisa seolah hilang setelah meminum kopi. b. Stimulus Fungsi Saraf dan Menambah Energi

Kafein membuat tubuh memproduksi ephinephrin, yaitu adrenalin dalam darah sehingga memberi stimulus pada sistem saraf. Kafein meningkatkan metabolisme dalam tubuh dari sebanyak 3-11\% lebih baik. Untuk melakukan proses perubahan ini kafein menggunakan energi dari lemak darah. Karena itu tubuh akan terasa berenergi dan bersemangat.

c. Meredakan Sakit Kepala

Kafein yang terkandung dapat membantu mengurangi rasa sakit migrain dan sakit kepala ringan akibat peradangan. Saat sakit kepala, pembuluh darah membengkak dan menyebabkan aliran darah tidak lancar tapi kafein dapat melebarkan aliran darah sehingga rasa sakit dapat berkurang.

Salah satu aspek yang tidak kalah pentingnya untuk dikelola para wirausahawan adalah Sumber Daya Manusia (SDM) yang dimilikinya. Manusia (karyawan) yang menjadi motor penggerak kegiatan usaha perlu dikelola secara professional. Aspek sumber daya manusia merupakan aspek yang mempengaruhi dalam pelaksanaan kinerja suatu perusahaan. Dalam aspek ini akan dikaji mengenai sumber tenaga kerja yang dipilih untuk dipekerjakan, sistem rekrutmen/seleksi karyawan, jumlah dan tingkat pendidikan, sistem penggajian, pelatihan, dan pengembangan karyawan dari sumber daya manusia yang dimiliki oleh karyawan. Dalam sistem recruitment/seleksi pegawai dalam usaha LMDH ini tidak ada syarat khusus, hanya saja untuk pegawai tetap minimal pendidikan terakhirnya adalah SMP (Sekolah Menengah Pertama) sedangkan untuk pegawai tidak tetap yang bekerja selama musim liburan atau panen raya adalah SD (Sekolah Dasar) dan memiliki kemampuan dalam bekerja juga bisa bertanggung jawab. Jumlah karyawan dan tingkat pendidikan pada LMDH ini tidak menentu jumlah, hanya saja ada beberapa pegawai tetap dengan rincian sebagai berikut: 
Tabel 2. Jumlah Karyawan Berdasarkan Tingkat Pendidikan

\begin{tabular}{lc}
\hline \multicolumn{1}{c}{ Tingkat Pendidikan } & Jumlah \\
\hline Sarjana S.1 & - \\
Diploma (D1, D2, D3) & - \\
SMA/SMK/MA & 2 orang \\
SMP/SLTP & 6 orang \\
SD & - \\
Tidak Tamat SD & - \\
\hline Jumlah Total & $\mathbf{8}$ orang \\
\hline
\end{tabular}

Tabel 3. Jumlah Karyawan Berdasarkan Unit

\begin{tabular}{|c|c|}
\hline \multicolumn{2}{|c|}{ Kerja } \\
\hline Jabatan & Jumlah \\
\hline Pimpinan/Pemilik & 1 orang \\
\hline Sekretaris & 1 orang \\
\hline Keuangan & 1 orang \\
\hline Bagian Produksi & 8 orang \\
\hline Bagian Pemasaran & - \\
\hline Jumlah Total & 11 orang \\
\hline
\end{tabular}

Berdasarkan Tabel 2, diketahui bahwa jumlah karyawan tetap yang ada di LMDH adalah 8 orang. Lulusan SMA terdapat 2 orang dan lulusan SMP terdapat 6 orang.

Berdasarkan Tabel 3, terdapat 11 orang dari total keseluruhan pegawai yang bekerja di LMDH. Yaitu 1 orang pimpinan/pemilik, 1 orang sekretaris, 1 orang keuangan, dan 8 orang bekerja di bagian produksi. LMDH tidak memiliki bagian pemasaran

Berdasarkan Tabel 4, seluruh pegawai tetap yang ada di LMDH mendapatkan tarif/upah yang sama rata. Dengan tarif/upah tiap satu harinya yaitu Rp. 350.000. Hanya saja untuk pemilik, sekretaris, dan bagian keuangan memiliki tarif/ upah yang berbeda.
Setiap perusahaan pada suatu waktu (periode) memiliki kewajiban untuk melaporkan semua kegiatan keuangannya. Laporan ini berisi jumlah aktivitas yang berhubungan dengan uang masuk (pendapatan) dan uang keluar (biayabiaya), sehingga terlihat besaran angka-angka yang mampu menjelaskan keuangan perusahaan dalam suatu periode. Berdasarkan identifikasi permasalahan mitra dalam hal keuangan menjadi persoalan klasik pelaku usaha (mikro/kecil) saat pencatatan keseharian, banyak ditemukan masalah tidak teratur atau tidak rutin mencatat pemasukan dan pengeluaran keuangan. Hal ini karena petugas yang mencatat tidak memahami pentingnya melakukan pencatatan keuangan, selain itu usaha mitra memang tidak menyediakan tenaga khusus yang fokus kepada pengeloalaam keuangan. Solusi dalam pelatihan/ bimteks.pendampingan penyusunan laporan keuangan, luaran yang diharapkan bahwa mitra akan semakin menyadari perlunya mencatat setiap aktivitas maupun transaksi keuangan dengan tujuan memperoleh hasil-hasil usaha maupun biaya atau beban yang dikeluarkan.

Pemasaran adalah suatu upaya dari produsen produk atau jasa untuk dapat mengidentifikasi calon-calon pembeli yang akan dijadikan suatu parameter dalam membuat rancangan bisnisnya. Agar dapat mengidentifikasi calon-calon pembeli tersebut, maka produsen terlebih dahulu membuat rencana pemasaran. Dalam dunia usaha, pasar dan pemasaran merupakan dua sisi yang tidak dapat dipisahkan satu sama lainnya. Pasar dan pemasaran memiliki tingkat ketergantungan yang tinggi dan saling memengaruhi satu sama lainnya. Pasar tanpa pemasaran tidak ada artinya, demikian pula sebaliknya. Dengan kata lain, setiap ada kegiatan pasar selalu diikuti oleh pemasaran dan setiap kegiatan pemasaran adalah untuk mencari atau menciptakan pasar.

Tabel 4. Sistem Pengupahan Karyawan

\begin{tabular}{lccccc}
\hline \multicolumn{1}{c}{ Jenis Kegiatan } & $\begin{array}{c}\text { Tarif/Upah } \\
\text { Per hari }\end{array}$ & $\begin{array}{c}\text { Jumlah } \\
\text { Tenaga Kerja }\end{array}$ & $\begin{array}{c}\text { Jumlah Hari } \\
\text { Kerja/Tahun }\end{array}$ & $\begin{array}{c}\text { Jumlah } \\
\text { (Rp) }\end{array}$ \\
\hline Pengupasan Buah Kopi (Cery) & Rp. 350.000 & 2 orang & 360 hari & Rp. & 252.000 .000 \\
Fermentasi Biji Kopi & Rp. 350.000 & 3 orang & 360 hari & Rp. & 378.000 .000 \\
Penjemuran Biji Kopi & Rp. 350.000 & 3 orang & 360 hari & Rp. & 378.000 .000 \\
\hline
\end{tabular}

Total Upah Tenaga Produksi

Sistem Harian

Rp. 1.008 .000 .000 
Berdasarkan wawancara dan identifikasi permasalahan mitra dalam hal pemasaran juga menjadi persoalan klasik pelaku usaha (mikro/kecil), mitra tidak melakukan upaya maksimal dalam melakukan promosi produk pengolahan kopi, hal ini terbukti berdasarkan hasil wawancara bahwa kebanyakan konsumen sendiri yang mendatangi mitra untuk melakukan pembelian produk. Konsumen tersebut adalah individu maupun kelompok, baik dari pelaku usaha (coffee shop), maupun konsumen (distributor/agen). Solusi dalam Pelatihan/ Bimteks/Pendampingan pemasaran, luaran yang diharapkan bahwa mitra akan terbuka wawasan serta pemikirannya bahwa di saat sekarang harus proaktif dalam mempromosikan produk, melalui media sosial maupun konvensional dengan harapan agar produk biji kopi semakin dikenal oleh masyarakat, bukan hanya di wilayah Pangalengan saja, tetapi bisa menjangkau wilayah lainnya.

\section{SIMPULAN}

Kegiatan PKM ini sudah dilaksanakan sesuai dengan tahapan kegiatan mulai dari persiapan/menyusun kegiatan, koordinasi tim pelaksana, penyiapan pelatih/pembimbing teknis/pendamping dan Mitra, penyusunan jadwal kegiatan program, pelaksanaan kegiatan pelatihan/pembimbing teknis/pendamping dan fasilitasi, serta pelaksanaan Monitoring dan evaluasi.

Pelaksanaan pelatihan/bimteks/ pendampingan dilakukan dengan empat bidang (produksi, sumber daya manusia, keuangan, serta produksi) dilengkapi dengan materi terkait. Pengelolaan usaha (manajerial), dari aspek Produksi sebaiknya Mitra memiliki kegiatan usaha lanjutan yang berhubungan dengan biji kopi. Produk yang dihasilkan tidak hanya biji kopi (gabah) tetapi bisa diolah kembali menjadi bubuk kopi (berasan). Aspek Keuangan, mitra sebaiknya ada pegawai khusus yang menangani bagian keuangan agar lebih fokus kepada pencatatan pemasukan dan pengeluaran usaha. Aspek Pemasaran. Mitra sebaiknya memasarkan produk ke daerah luar kota dengan menggunakan sistem online dan offline melalui pembuatan iklan di media sosial dan koran. Aspek sumber daya manusia, mitra sebaiknya sering mengikuti kegiatan pelatihan agar dapat diketahui kemampuan dan kemauan pegawai.

\section{PERSANTUNAN}

Alhamdulillah, segala puji syukur kami panjatkan kehadirat Allah Swt, karena hanya atas rahmat dan hidayah-Nya, sehingga kami dapat menyelesaikan kegiatan program kepakaran/ intern bidang pengabdian kepada masyarakat dengan topik PKM pelaku usaha pengolahan kopi di Desa Warnasari Kecamatan Pangalengan Kabupaten Bandung.

Kami ucapkan terima kasih kepada Pimpinan Prodi dan Fakultas Ilmu Sosial dan Ilmu Politik serta Pimpinan P3M Universitas Pasundan Bandung. Kami juga sampaikan apresiasi kepada pemilik usaha pengolahan kopi di Kecamatan Pangalengan, Kabupaten Bandung yang sudah berkenan menjadi mitra dalam pengabdian kali ini

\section{REFERENSI}

Audry, R. J., \& Djuwendah, E. (2018). Analisis Pendapatan Usahatani Kopi Java Preanger pada Kelompok Tani Margamulya Desa Margamulya Kecamatan Pengalengan Bandung. Jurnal Ilmu Pertanian Dan Peternakan, 6(1), 31-38.

Biologi, J., No, V., Usman, D., Suprihadi, A., \& Kusdiyantini, E. (2015). Fermentasi Kopi Robusta (Coffea Canephora) Menggunakan Isolat Bakteri Asam Laktat dari Feces Luwak dengan Perlakuan Lama Waktu Inkubasi. Jurnal Akademika Biologi, 4(3), 31-40.

Djuwendah, E., Karyani, T., Sadeli, A. H., \& Kusno, K. (2018). Agroindustrialisasi Kopi Arabika Java Preanger di Desa Margamulya Kecamatan Pangalengan Kabupaten Bandung. 3(1).

Edowai, D. N., \& Tahoba, A. E. (2018). Proses produksi dan Uji Mutu Bubuk Kopi Arabika (coffea arabica L) Asal Kabupaten Dogiyai, Papua. Agriovet, 1(1), 1-18. 
Mulyana, dkk - PKM Pelaku Usaha Pengolahan Kopi Desa Warnasari ...

Id, S. (2020). Aman Melalui Teknik Mutasi. Doc X. 13(02).

Noor, I. H. (2010). Penelitian dan Pengabdian Masyarakat pada Perguruan Tinggi. Jurnal Pendidikan Dan Kebudayaan, 16(3), 285. https://doi.org/10.24832/jpnk.v16i3.462

Sarfiah, S. N., Atmaja, H. E., \& Verawati, D. M. (2019). Umkm sebagai Pilar Membangun Ekonomi Bangsa Msmes the Pillar for Economy. Jurnal REP (Riset Ekonomi Pembangunan), 4(2), 137-146.

Segarwati, Y., Fitrananda, C., Iqbal, M., \& Rahiem, V. (2020). Pengembangan Pemasaran Online untuk Pelaku Usaha di Desa Warnasari, Kecamatan Pangalengan, Kabupaten Bandung. Kaibon Abhinaya: Jurnal Pengabdian Masyarakat, 2(2), 45-52.

Supriyanto, -. (2012). Pemberdayaan Usaha Mikro, Kecil dan Menengah (UMKM) sebagai Salah Satu Upaya Penanggulangan Kemiskinan. Jurnal Ekonomi Dan Pendidikan, 3(1), 1-16. https://doi. org/10.21831/jep.v3i1.627

Tesavrita, C., \& Martaleo, M. (2013). Perancangan Pabrik Pengolahan Biji Kopi dan Analisis Kelayakannya (Studi Kasus Di Kabupaten Bandung). Lembaga Penelitian Dan Pengabdian Kepada Masyarakat Universitas Katolik Parahyangan, 61. 